\title{
ASPECTS REGARDING STRENGTH AND AGILITY IN JUNIOR III WATER POLO PLAYERS
}

\author{
Gheorghe MARINESCU ${ }^{1}$, Laurențiu Daniel TICALĂ ${ }^{1 *}$, Adrian RĂDULESCU ${ }^{1}$, \\ Cristina VĂRZARU ${ }^{1}$, Ana Maria MUJEA ${ }^{1}$, Elena Daniela SALIH KHIDIR ${ }^{2}$ \\ ${ }^{1}$ National University of Physical Education and Sport, Faculty of Physical Education and Sport, \\ Bucharest, Romania \\ ${ }^{2}$ Aspetar Orthopaedic and Sports Medicine Hospital, Doha, Qatar \\ *Corresponding author: ticala_laurentiu@yahoo.com
}

https://doi.org/10.35189/dpeskj.2020.59.4.11

\begin{abstract}
The research integrates methods of assessment and analysis of one facet of psychomotricity, namely the strength and agility expressed in a nonspecific (land-based) environment by junior III water polo players. The focus is on the application of two subtests, subtest 1 - Running speed and agility, and subtest 2 - Strength, which are part of the Bruininks-Oseretsky Test of Motor Proficiency, Second Edition. This test battery was applied to high-performance athletes who were in the sights of the national team and were basic members of their club teams. The athletes are born in 1997, play match by match and belong to Steaua School Sports Club 3 (national champion team) and Emil Racoviță Sports College (ranked 3rd in the national championship). The test was conducted on 7 August 2012 in the sports hall of UNEFS Bucharest. The results have shown that, out of the 24 tested athletes, $87 \%$ (21 athletes) fall into the average category, and 13\% (3 athletes) fall into the above-average category. Mean composite scores are $X=47.25$ points for the athletes from Emil Racoviță and X=53.17 points for those from Steaua. The mean difference is 5.92 points (11.1\%) in favour of Steaua athletes. This research has contributed to obtaining, through nonspecific (land-based) means, valuable information on the level of strength and agility of junior III water polo players, which is useful for coaches to introduce technical exercises in their training sessions in order to develop strength and agility under specific competitive conditions and the constant time pressure.
\end{abstract}

Keywords: strength, agility, water polo, Bruininks-Oseretsky Test.

\section{Introduction}

After accessing the Google Scholar database, approximately 4,870 specialised articles on psychomotricity have been identified, which shows an increased interest of specialists in exploring this topic. In the Romanian literature, specialists in the field (Epuran, 1976; Horghidan, 1997; Dragnea \& Bota, 1999; Stănescu, 2002; Mitrache \& Tüdös, 2004) also studied the issue of psychomotricity. The large number of published studies suggests the permanent interest of experts in clarifying and highlighting the importance of this concept.

We present below a review of the literature on psychomotricity. The conceptual delimitations of psychomotricity converge to emphasise the connection between mental and motor aspects. The interventions of health specialists towards psychomotricity have demonstrated the existence of a constant interaction between motor and mental sides, therefore between body and mind (Azedevo Fernandes et al., 2018). Psychomotricity is a complex function that integrates and combines motor and mental elements (Cojanu \& Vișan, 2017). The progressive acquisition of skills related to both mental and motor activities is defined as psychomotor development (Teixeira Costa et al., 2015). Psychomotricity is an expression of 
the maturity and integration of mental and motor functions at a level that requires the proper integration of an individual into an environment (Epuran, 1976).

Psychomotricity is a structure whose function expresses complex inter-determinative relationships. Motor and mental aspects mutually condition each other, which is why addressing the motor issue beyond the mental determinants reduces motor acts to automatism. Mental and motor functions are fundamental elements of adaptation. (Dragnea et al., 2006)

Recent studies analysing psychomotricity are focused on motor structures and their relationship with the body schema, ideomotor skills, laterality and spatial-temporal orientation, but also on the means of learning and the social adaptation of the individual (Iconomescu et al., 2017).

The science of psychomotricity is understood as a transdisciplinary field that studies and investigates the mutual and systemic relationships and influences between the psyche and the body, between the psyche and motricity, which are inherent to the unique and evolving human personality that characterises the human being in its multiple and complex biopsychosocial, emotional and social-cognitive manifestations. Psychomotricity starts from a holistic notion of the body and motricity, considering the human being as a complex organism that integrates the soma and the psyche. (da Fonseca, 2010)

Psychomotricity generally studies the human being's progress and motor acquisitions coordinated by mental activity and achieved by creative, emotional and social development, depending on oneself and the social environment (Talaghir et al., 2019). Psychomotricity allows knowing the human being in terms of interrelation between mental and motor aspects and plays a significant role for the psycho-behavioural system of athletes (Bădău et al., 2010).

Drăgan (2002) highlights that the motor skills necessary for a water polo player, such as explosive power (speed-strength), strength-endurance and endurance-speed (in a permanent back-and-forth movement), give this game a dynamic and spectacular character (like in basketball).

Agility is considered a rapid movement of the whole body, with a change in speed or direction in response to a stimulus (Sheppard \& Young, 2006). Generally, the definition of agility is simple but at the same time its context is highly complex, meaning that it can be widely used in practice (Mackala et al., 2020).

Agility plays an important role in both training and competition. Agility is a significant component of performance because it includes the ability to perform fast and efficient movements with the whole body or only with its segments (Verstegen \& Marcello, 2001; Holmberg, 2015; Young et al., 2015; Paul et al., 2016; Coh et al., 2018).

While the classical definition of agility refers to the ability of changing the direction or speed of a movement as quickly and precisely as possible, recent definitions have integrated a cognitive component that includes factors such as prediction, visual and perceptual recognition, reaction speed and attention abilities (Coh et al. 2018; Sheppard \& Young, 2006). Decisionmaking and perception are often described as discriminatory factors (Paul et al., 2016).

Agility is an important characteristic of team sports. There is a growing interest in factors that influence agility performance but also in appropriate testing protocols and training strategies to assess and improve this ability (Paul et al., 2016).

Agility has relationships with both motor skills (such as strength and power) and cognitive components (Sheppard \& Young, 2006). The comprehensive definition of agility recognises 
the importance of motor skills (strength and endurance), cognitive processes (motor learning) and technical abilities (biomechanics) involved in achieving performance (Sheppard \& Young, 2006).

It has been demonstrated that, compared to experienced volleyball and basketball players, water polo players have better scores on decision-making, visual reaction time and spatial orientation, while basketball players are better on prediction and selective attention, and volleyball players are better on perceptual speed, focused attention, prediction and estimation of speed and direction of a moving object (Kioumourtzoglou et al., 1998). The study conducted by a group of authors (Oikonomou et al., 2019) has shown that, in young Olympic team players, mixed endurance training and strength training may be associated with a favourable vascular profile.

Botonis et al. (2018) state that the recording of muscle strength level and fitness indices of elite water polo players is of great scientific and practical interest for two reasons: on the one hand, it provides a picture of the upper limits of adaptations derived from long-term water polo training and, on the other hand, it provides scientific evidence to coaches regarding the selection and fitness profile of water polo players.

Given the multitude of dynamic actions that take place throughout a water polo game (physical contact/fight, fast swim, offensive and defensive actions), an appropriate level of strength development is essential for water polo players (Botonis, Toubekis, \& Platanou, 2019).

In water polo, daily training lessons in the preparatory period usually include a high volume of interval training along with strength and specific water polo training (Botanies et al., 2019). In the water polo game, athletes must have quick reactions with both dominant and nondominant hands as they often block the opponent's shots on goal, which requires explosive movements (Gardasevic et al., 2019).

\section{Research hypothesis}

Testing strength and agility through non-specific (land-based) means provides information on the in-water performance of young polo players (junior III).

\section{Methodology}

\section{Methods used}

This paper is an ascertaining pedagogical experiment, as part of an extensive research of major interest for the field. Among the research methods used, we mention: test method Bruininks-Oseretsky Test of Motor Proficiency, Second Edition (BOT-2), non-parametric Mann-Whitney U Test, effect size index, graphical method, mathematical and statistical method with the statistical parameters of central tendency, arithmetic mean (X), statistical parameters of dispersion, standard deviation (S), and coefficient of variation (Cv) (Popa, 2008). 


\section{Period, site and participants}

The present study aims to diagnose the exercise capacity of junior III, the results and the way of achieving them representing a keystone in the efficient training of water polo players.

The experiment involved 24 athletes from two water polo clubs in Bucharest, registered in the National Championship: Steaua School Sports Club 3 (CS Steaua) (1st place) and Emil Racoviță Sports College (CS Racoviţă) (3rd place). The athletes are born in 1997, play match by match for their club teams and are in the sights of the national team. The test was conducted on 7 August 2012 in the sports hall of UNEFS Bucharest.

\section{The test used}

The Bruininks-Oseretsky Test of Motor Proficiency, Second Edition (BOT-2), is an individually administered test battery that relies on a series of very well-defined objectives focused on assessing a wide range of motor skills in subjects aged 4 to 21 years. Since its publication in 1978, the original form of the Bruininks-Oseretsky Test of Motor Proficiency (BOTMP) has been the most widely used test battery to measure psychomotor ability. (Crowe, 1989; Ulrich, 1985) It has gained the trust of specialists in various fields because it is able to provide valuable information on a wide range of motor skills. Moreover, the above test helps evaluators to identify subjects who have certain gaps in motor control, this assessment tool being relatively easy to administer and interpret, and, last but not least, quite agreed by the tested subjects. This test battery was designed for physical therapists, psychologists, physical education teachers, coaches (and not only), providing them with an efficient and reliable instrument for measuring fine and gross motor skills.

Strength and agility: include the coordination and control of large muscle groups involved in locomotion, especially during recreational and competitive activities.

Description of subtests (Gozu, 2011)

Subtest 1: Running speed and agility

Activities in this subtest include running back and forth, jumping on one leg or both legs and crossing the balance beam. During the running speed test (measured in seconds), the examiner has the opportunity to also make clinical observations regarding the quality of subject's movement.

\section{Content:}

- Item 1: shuttle run;

- Item 2: sidestep over the balance beam;

- Item 3: one-leg jumps on the spot;

- Item 4: side jumps on one leg;

- Item 5: side jumps on both legs. 
Subtest 2: Strength

Activities in this subtest measure the trunk, upper body and lower body strength. This subtest plays an essential role in the process of assessing motor skills, because strength is an important component of gross motor performance involved in daily activities.

Content:

- Item 1: standing long jump;

- Item 2: full push-ups/ push-ups on the knees;

- Item 3: trunk lifts from the supine position with bent knees;

- Item 4: standing with the back against the wall, knees bent at a 90-degree angle;

- Item 5: from lying face down, with arms and legs outstretched, lifting the head, chest, arms and legs simultaneously and holding this position.

\section{Results}

Following the analysis and interpretation of the results obtained in subtest 1 (Running speed and agility), we can mention that the minimum value recorded by Racoviță athletes is 8 points, while the maximum value is 17 points, the range of motion being 9 points; the minimum value recorded by Steaua athletes is 10 points, while the maximum value is 21 points, the range of motion being 11 points; the median has the value 11.50 points and the arithmetic mean is 11.92 for Racoviță athletes, while for Steaua athletes, the median has the value 16.50 points and the arithmetic mean is 15.58 .

Table 1. Analysis of scores obtained in subtest 1 - Running speed and agility

\begin{tabular}{lcccccccc}
\hline $\begin{array}{c}\text { Sports } \\
\text { club }\end{array}$ & Mean & $\begin{array}{c}\text { Mean } \\
\text { difference }\end{array}$ & Median & $\begin{array}{c}\text { Standard } \\
\text { deviation }\end{array}$ & Minimum & Maximum & $\begin{array}{c}\text { Range of } \\
\text { motion }\end{array}$ & Cv \\
\hline Steaua & 15.58 & -3.67 & 16.50 & 2.94 & 10 & 21 & 11 & $18.9 \%$ \\
Racoviță & 11.92 & $(-23.5 \%)$ & 11.50 & 3.40 & 8 & 17 & 9 & $28.5 \%$ \\
\hline
\end{tabular}

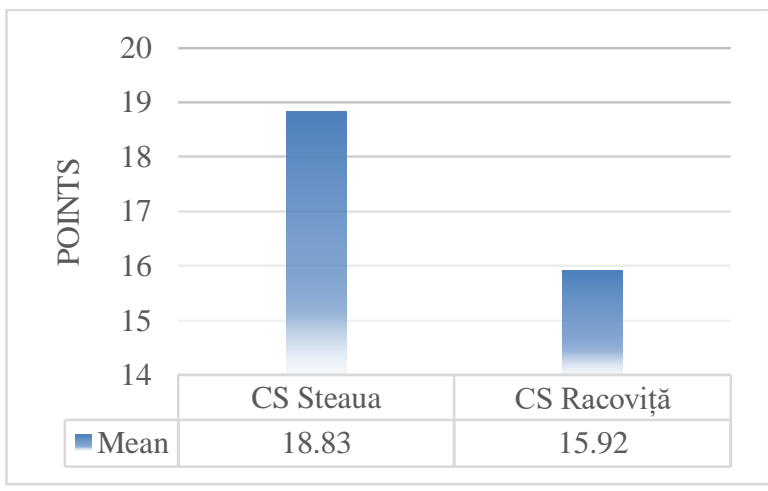

\begin{tabular}{|ccc|}
\hline \multicolumn{3}{|c|}{ Running speed and agility } \\
Scores \\
\hline Scores & CS & CS \\
& Steaua & Racoviță \\
\hline Below average & 1 & 6 \\
Average & 10 & 6 \\
Above average & 1 & 0 \\
\hline Total & 12 & 12 \\
\hline
\end{tabular}

Figure 1. Comparison of average scores obtained in subtest 1 - Running speed and agility

The mean difference between the scores obtained by both groups of athletes is 3.67 points in favour of the athletes from CS Steaua, which indicates that they are about $23.5 \%$ superior in this parameter, and therefore have achieved a higher score in this subtest. In terms of group 
homogeneity, the standard deviation is \pm 2.94 points and the coefficient of variation is $18.9 \%$ for Steaua athletes, which indicates a relative group homogeneity in the tested parameter; the standard deviation is \pm 3.40 points and the coefficient of variation is $28.5 \%$ for the athletes from CS Racoviță, which indicates that the group lacks homogeneity in the tested parameter. (Table 1 and Figure 1)

Application of the non-parametric Mann-Whitney $U$ Test shows that there are no statistically significant differences between the two groups, $\mathrm{z}=-0.247, \mathrm{p}=0.013<0.05$, but the value of the effect size index (0.51) reveals a large-to-very large difference between the two groups (Table 2).

Table 2. Non-parametric Mann-Whitney U Test in subtest 1 - Running speed and agility

\begin{tabular}{lcccccc}
\hline \multirow{2}{*}{ Running speed } & Sports club & $\mathrm{N}$ & $\begin{array}{c}\text { Mean } \\
\text { ranks }\end{array}$ & $\begin{array}{c}\text { Rank } \\
\text { sum }\end{array}$ & Test parameters & Result \\
\cline { 2 - 7 } and agility & Steaua & 12 & 16.04 & 192.50 & Mann-Whitney U & 29.50 \\
& Racoviță & 12 & 8.96 & 107.50 & Z & -2.476 \\
& Total & 24 & & & P (2-tailed) & 0.013 \\
& & & & & Effect size & 0.51 \\
\hline
\end{tabular}

Figure 2 highlights the percentage scores obtained by each team in the Running speed and agility parameter.
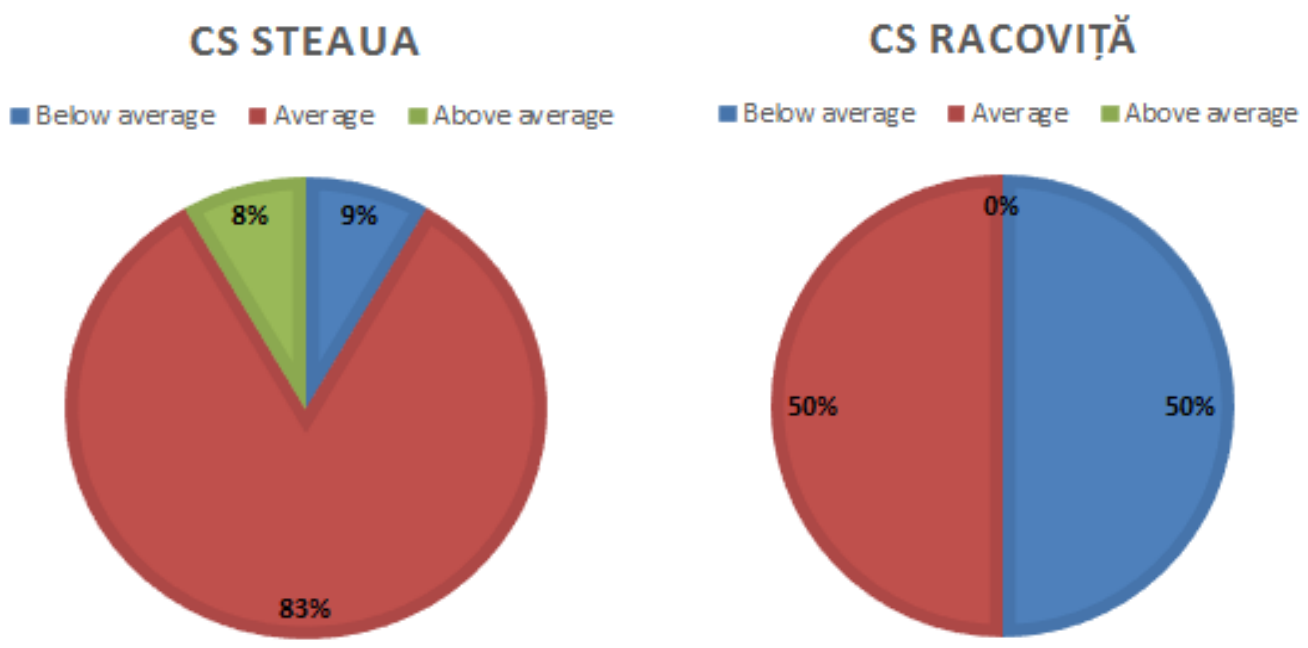

Figure 2. Percentage distribution of scores obtained in subtest 1 - Running speed and agility

Following the analysis and interpretation of the results obtained in subtest 2 (Strength), we can mention that the minimum value recorded by Racoviţă athletes is 12 points, while the maximum value is 23 points, the range of motion being 11 points; the minimum value recorded by Steaua athletes is 11 points, while the maximum value is 22 points, the range of motion being 11 points; the median has the value 15 points and the arithmetic mean is 15.92 points for Racoviță athletes, while for Steaua athletes, the median has the value 19.50 points and the arithmetic mean is 18.83 points. The mean difference between the scores obtained by both groups of athletes is 2.92 points in favour of the athletes from CS Steaua, which indicates that 
they are about $15.5 \%$ superior in this parameter, and therefore have achieved a higher score in this subtest. In terms of group homogeneity, the standard deviation is \pm 3.01 points and the coefficient of variation is $16 \%$ for Steaua athletes, which indicates a relative group homogeneity in the tested parameter; the standard deviation is \pm 3.15 points and the coefficient of variation is $19.8 \%$ for the athletes from CS Racoviță, which indicates a relative group homogeneity in the tested parameter. (Table 3 and Figure 3)

Table 3. Analysis of scores obtained in subtest 2 - Strength

\begin{tabular}{lcccccccc}
\hline $\begin{array}{c}\text { Sports } \\
\text { club }\end{array}$ & Mean & $\begin{array}{c}\text { Mean } \\
\text { difference }\end{array}$ & Median & $\begin{array}{c}\text { Standard } \\
\text { deviation }\end{array}$ & Minimum & Maximum & $\begin{array}{c}\text { Range of } \\
\text { motion }\end{array}$ & Cv \\
\hline Steaua & 18.83 & -2.92 & 19.50 & 3.01 & 11 & 22 & 11 & $16.0 \%$ \\
Racoviță & 15.92 & $(-15.5 \%)$ & 15.00 & 3.15 & 12 & 23 & 11 & $19.8 \%$ \\
\hline
\end{tabular}
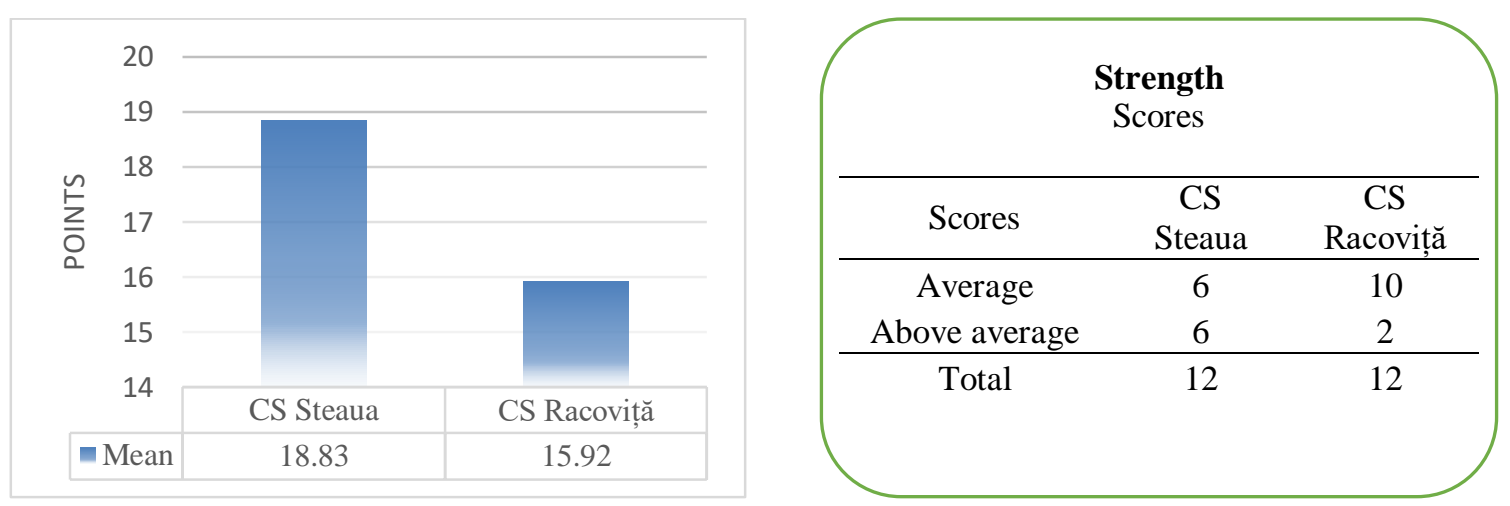

Figure 3. Comparison of average scores obtained in subtest 2 - Strength

Application of the non-parametric Mann-Whitney $U$ Test shows that there are no statistically significant differences between the two groups, $\mathrm{z}=-2.209, \mathrm{p}=0.027<0.05$, but the value of the effect size index (0.45) indicates a medium-to-large difference between the two groups (Table 4).

Table 4. Non-parametric Mann-Whitney U Test in subtest 2 - Strength

\begin{tabular}{ccccccc}
\hline \multirow{3}{*}{ Strength } & Sports club & N & $\begin{array}{c}\text { Mean } \\
\text { ranks }\end{array}$ & $\begin{array}{c}\text { Rank } \\
\text { sum }\end{array}$ & Test parameters & Result \\
\cline { 2 - 7 } & Steaua & 12 & 15.67 & 188.00 & Mann-Whitney U & 34.00 \\
& Racoviță & 12 & 9.33 & 112.00 & Z & -2.209 \\
& Total & 24 & & & P (2-tailed) & 0.027 \\
& & & & & Effect size & 0.45 \\
\hline
\end{tabular}

Figure 4 highlights the percentage scores obtained by each team in the Strength parameter. 

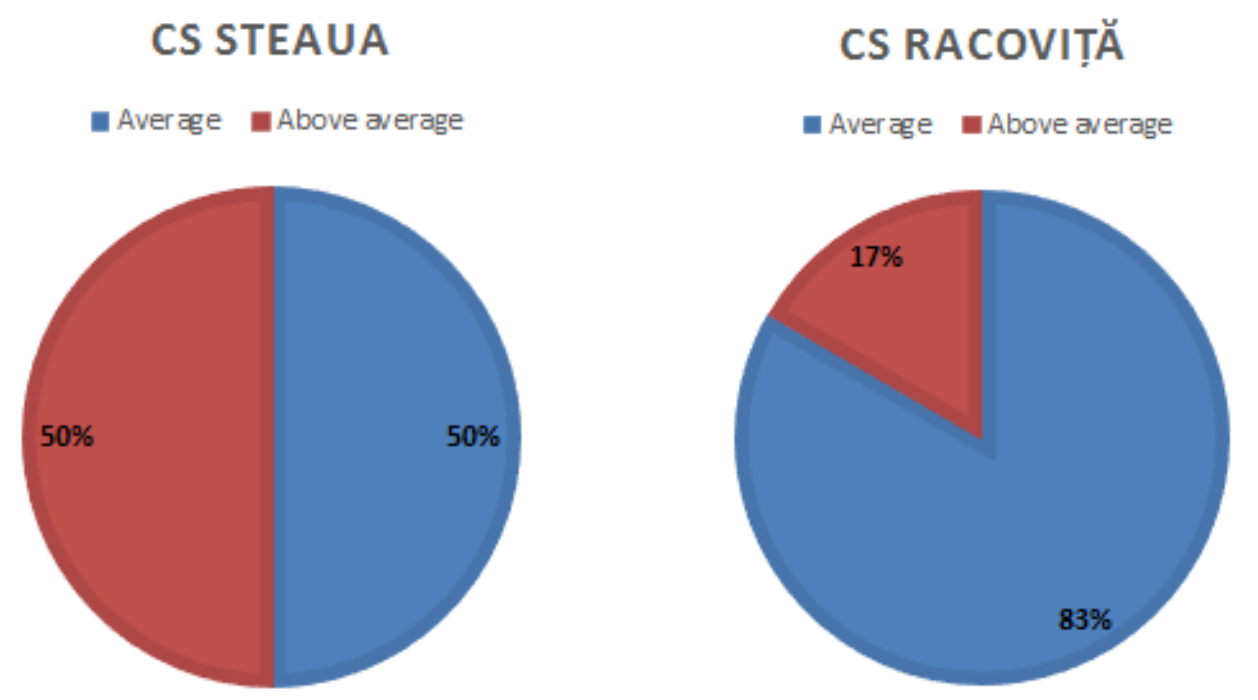

Figure 4. Percentage distribution of scores obtained in subtest 2 - Strength

Following the analysis and interpretation of composite scores obtained in the Strength and agility parameter, we can mention that mean composite scores are $X=47.25$ points for the athletes from Emil Racoviţă and $X=53.17$ points for those from Steaua. The mean difference between the scores obtained by both groups of athletes is $X=5.92$ points $(11.1 \%)$ in favour of the athletes from CS Steaua, which indicates that they have achieved a higher score in this subtest. (Table 5 and Figure 5)

Table 5. Analysis of scores obtained in the Strength and agility parameter

\begin{tabular}{lcccccccc}
\hline $\begin{array}{c}\text { Sports } \\
\text { club }\end{array}$ & Mean & $\begin{array}{c}\text { Mean } \\
\text { difference }\end{array}$ & Median & $\begin{array}{c}\text { Standard } \\
\text { deviation }\end{array}$ & Minimum & Maximum & $\begin{array}{c}\text { Range of } \\
\text { motion }\end{array}$ & Cv \\
\hline Steaua & 53.17 & -5.92 & 52.50 & 4.80 & 46 & 63 & 17 & $9.0 \%$ \\
Racoviță & 47.25 & $(-11.1 \%)$ & 45.00 & 6.45 & 41 & 61 & 20 & $13.7 \%$ \\
\hline
\end{tabular}
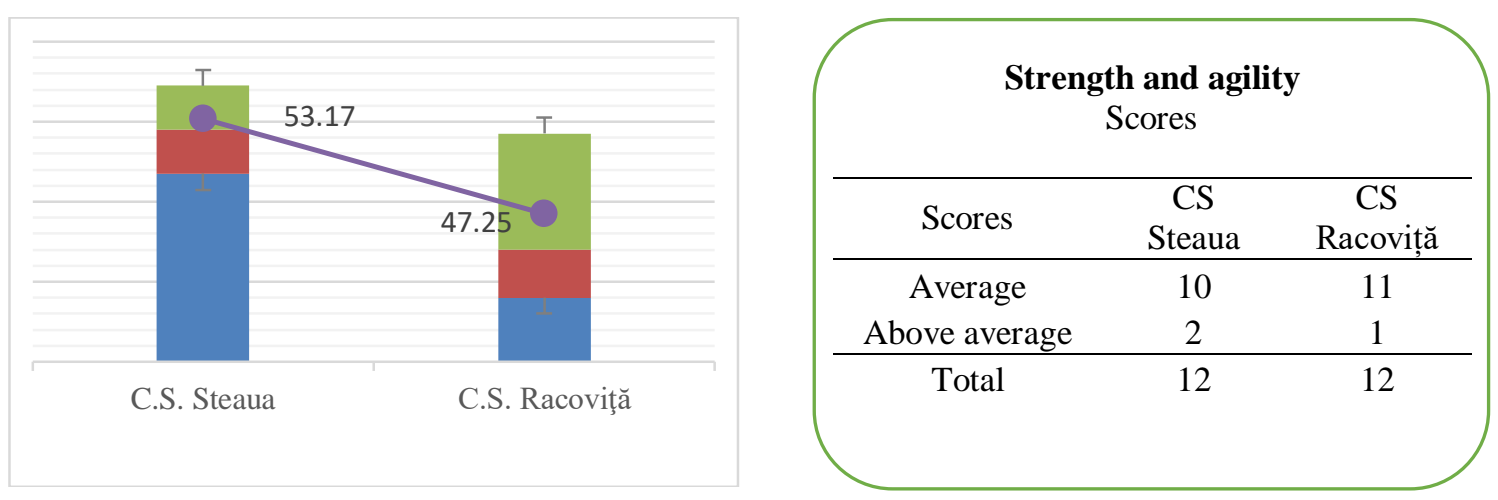

Figure 5. Comparison of average scores obtained in the Strength and agility parameter

The results range from 46 points to 63 points for CS Steaua athletes and from 41 points to 61 points for CS Racoviţă athletes. The coefficient of variation is $13.7 \%$ for Racoviţă athletes, 
which shows that they form a relatively homogeneous group, with large dispersion of results. The coefficient of variation is $9.0 \%$ for Steaua athletes, which indicates that they form a homogeneous group, with low dispersion of results.

The non-parametric Mann-Whitney U Test demonstrates that there are statistically significant differences between the two groups, $\mathrm{z}=-2.290, \mathrm{p}=0.022<0.05$. The effect size index (0.49) shows a medium-to-large difference between the two groups. (Table 6)

Table 6. Non-parametric Mann-Whitney U Test in the Strength and agility parameter

\begin{tabular}{lcccccc}
\hline & Sports club & $\mathrm{N}$ & $\begin{array}{c}\text { Mean } \\
\text { ranks }\end{array}$ & Rank sum & Test parameters & Result \\
\cline { 2 - 6 } Strength and & Steaua & 12 & 15.79 & 189.50 & Mann-Whitney U & 32.50 \\
agility & Racoviță & 12 & 9.21 & 110.50 & Z & -2.290 \\
& Total & 24 & & & P (2-tailed) & 0.022 \\
& & & & & Effect size & 0.47 \\
\hline
\end{tabular}

Figure 6 highlights the percentage scores obtained by each team in the Strength and agility parameter.
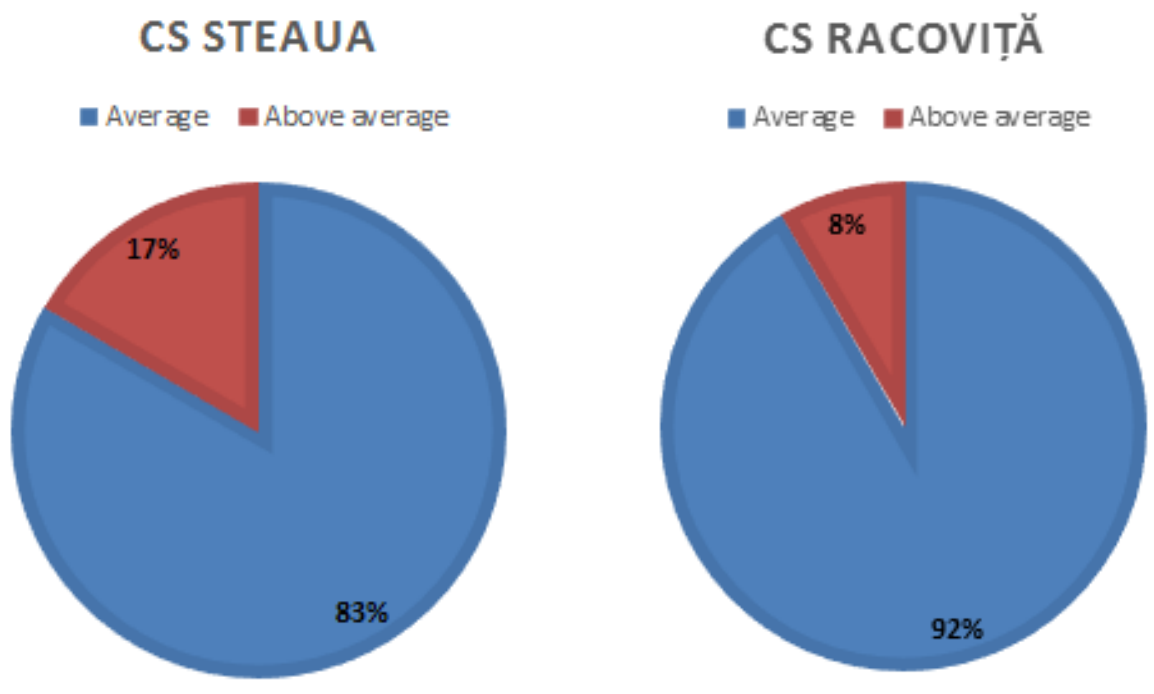

Figure 6. Percentage distribution of scores obtained in the Strength and agility parameter

\section{Conclusion}

General and specific physical training performed on dry land is particularly important for children to increase their in-water motor skills.

In terms of average composite scores, the results obtained by the athletes from CS Steaua are superior $(\mathrm{CS}$ Steaua $=53.16$; CS Racoviță $=47.25)$, the recorded difference being 5.91 points, which is why we consider that the psychomotor abilities gained through non-specific dry-land training are positively transferred to the in-water specific training by improving motor skills and abilities. 
Testing strength and agility through non-specific (land-based) means provides information on the in-water performance of young polo players (junior III) - the research hypothesis has been confirmed.

The results achieved in the championship by the athletes from CS Steaua versus the athletes from CS Racovităa are consistent with the results obtained after applying the BruininksOseretsky Test of Motor Proficiency, Second Edition (BOT-2).

\section{Authors' Contributions}

All authors have equally contributed to this study and should be considered as main authors.

\section{References}

Azedevo Fernandes, J. M. G., Barbosa Gutierres Filho, P. J., \& Gonçalves de Rezende, A. L. (2018). Psicomotricidade, jogo e corpo-em-relação: Contribuições para a intervenção. [Psychomotricity, play, and body-in-relation: Contributions to intervention]. Cadernos Brasileiros de Terapia. Ocupational, São Carlos, 26(3), 702-709. https://doi.org/10.4322/2526-8910.ctoEN1232

Bădău, D., Bădău, A., Paraschiv, F., Manolache, G. M., Talaghir, L.-G., \& Neagu, N. (2010). Level determination of space orientation depending on manual laterality and using artificial intelligence techniques. In Proceedings of the 9th WSEAS International Conference on Artificial Intelligence, Knowledge Engineering and Data Bases (pp. 108-113). https://pdfs.semanticscholar.org/d090/7bca506aa5857a908058c5a729ecaa9d2898.pdf?_ga $=2.133768526 .1163635721 .1597505052-1720258790.1588164446$

Botonis, P., Toubekis, A., Terzis, G., Geladas, N., \& Platanou, T. (2019). Effects on concurrent strength and high-intensity interval training on fitness and match performance in water-polo players. (2019). Journal of Human Kinetics, 67, 175-184. https://dx.doi.org/10.2478\%2Fhukin-2019-0001

Botonis, P., Toubekis, A., \& Platanou, T. (2018). Evaluation of physical fitness in water polo players according to playing level and positional role. Sports, 6(4): 157. https://dx.doi.org/10.3390\%2Fsports6040157

Botonis, P., Toubekis, A., \& Platanou, T. (2019). Physiological and tactical on-court demands of water polo. The Journal of Strength \& Conditioning Research, 33(11), 3188-3199. https://doi.org/10.1519/jsc.0000000000002680

Coh, M., Vodicar, J., Zvan, M., Simenko, J., Stodolka, J., Rauter, S., \& Mackala, K. (2018). Are change-of-direction speed and reactive agility independent skills even using the same movement pattern. The Journal of Strength \& Conditioning Research, 32(7), 1929-1936. https://doi.org/10.1519/jsc.0000000000002553

Cojanu, F., \& Vișan, P. (2017). New perspectives to develop psychomotor capacity for Romanian children from primary school. The European Proceedings of Social \& Behavioural Sciences, 23, 1423-1431. https://doi.org/10.15405/epsbs.2017.05.02.174

Crowe, T. K. (1989). Pediatric assessments: A survey of their use by occupational therapists in north-western school systems. Occupational Therapy Journal of Research, 9(5), 273-286. https://doi.org/10.1177\%2F153944928900900502

da Fonseca, V. (2010). Psicomotricidade: Uma visão pessoal [Psychomotricity: A personal view]. Construção Psicopedagógica, 18(17), 42-52. https://pdfs.semanticscholar.org/bb1b/74d236373c5469b565f9611829aa5c97ea20.pdf?_ga $=2.258405130 .1298880383 .1586599524-1867304646.1584903889$ 
Dragnea, A., \& Bota, A. (1999). Teoria activităților motrice [Theory of motor activities]. București: EDP.

Dragnea, A., Bota, A., Stănescu, M., Teodorescu, S., Șerbănoiu, S., \& Tudor, V. (2006). Educație fizică şi sport - Teorie şi didactică [Physical education and sport - Theory and didactics]. București: FEST.

Drăgan, I. (2002). Medicină sportivă [Sports medicine]. București: Editura Medicală.

Epuran, M. (1976). Psihologia educației fizice [Physical education psychology]. București: ANEFS.

Gardasevic, J., Akpinar, S., Stevo, P., \& Bjelica, D. (2019). Increased perceptual and motor performance of the arms of elite water polo players. Applied Bionics and Biomechanics. https://doi.org/10.1155/2019/6763470

Gozu, B. (2011). Dinamica factorilor motrici și psihomotrici la elevii din ciclul primar [Dynamics of motor and psychomotor factors in primary school students] (Teză de doctorat). UNEFS București.

Holmberg, P. M. (2015). Agility training for experienced athletes: A dynamical systems approach. Strength and Conditioning Journal, 31(5), 73-78.

https://doi.org/10.1519/SSC.0b013e3181b988f1

Iconomescu, T. M., Mindrescu, V., \& Talaghir, L. G. (2017). The importance of motion games in the psychomotor development of pre-schoolers during the physical education class. ERPA International Congresses on Education, 37. https://doi.org/10.1051/shsconf/20173701070

Kioumourtzoglou, E., Kourtessis, T., Michalopoulou, M., \& Derri, V. (1998). Differences in several perceptual abilities between experts and novices in basketball, volleyball and water polo. Perceptual and Motor Skills, 86(3 Pt 1), 899-912. https://doi.org/10.2466/pms.1998.86.3.899

Mackala, K., Vodǐcar, J., Žvan, M., Križaj, J., Stodolka, J., Rauter, S., \& Coh, M. (2020). Evaluation of the pre-planned and non-planed agility performance: Comparison between individual and team sports. International Journal of Environmental Research and Public Health, 17(3): 975. https://doi.org/10.3390/ijerph17030975

Mitrache, G., \& Tüdös, Ş. (2004). Psihomotricitate și limbaj [Psychomotricity and language]. București: Cartea Universitară.

Oikonomou, E., Siasos, G., Marinos, G., Zaromitidou, M., Athanasiou, D., Foundoulakis, P., Tsalamandris, S., Antonopoulos, A., Mistakidi, C. V., Vlachopoulos, C., \& Tousoulis, D. (2019). High intensity endurance and strength training in water polo Olympic team players: Impact on arterial wall properties. European Heart Journal, 40 (Suppl 1). https://doi.org/10.1093/eurheartj/ehz745.0111

Paul, D. J., Gabbett, T. J., Nassis, \& G. P. (2016). Agility in team sports: Testing, training and factors affecting performance. Sports Medicine, 46(3), 421-442. https://doi.org/10.1007/s40279-015-0428-2

Popa, M. (2008). Statistică pentru psihologie - Teorie și aplicații SPSS [Statistics for psychology - Theory and SPSS applications]. Iași: Polirom.

Sheppard, J. M., \& Young, W. B. (2006). Agility literature review: Classifications, training and testing. Journal of Sports Science, 24(9), 919-932. https://doi.org/10.1080/02640410500457109

Talaghir, L. G., Berdilă, A., \& Iconomescu, T. M. (2019). Study regarding psychomotor aspects approached by Romanian authors. Journal of Physical Education and Sport, 19(Suppl 6), 2297-2304. DOI: 10.7752/jpes.2019.s6347

Teixeira Costa, H. J., Abelairas-Gomez, C., Arufe-Giráldez, V., Pazos Couto, J. M., \& BarcalaFurelos, R. (2015). Influence of a physical education plan on psychomotor development profiles of preschool children. Journal of Human Sport and Exercise, 10(1), 126-140. https://doi.org/10.14198/jhse.2015.101.11 
Ulrich, D. A. (1985). Test of Gross Motor Development. Austin, TX: PRO-ED, Inc.

Verstegen, M., \& Marcello., B. (2001). Agility and coordination. In B. Foran (Ed.), High performance sports conditioning (pp. 139-165). Champaign, IL: Human Kinetics.

Young, W. B., Dawson, B., \& Henry, G. J. (2015). Agility and change of direction speed are independent skills: Implications for training for agility in invasion sports. International Journal of Sports Science Coaching, 10(1), 159-169.

https://doi.org/10.1260\%2F1747-9541.10.1.159 